\title{
Chiral Translation and Cooperative Self-Assembly of Discrete Helical Structures Using Molecular Recognition Dyads
}

Hiroshi Nakade, Brian J. Jordan, Hao Xu, Gang Han, Sudhanshu Srivastava, Rochelle R. Arvizo, Graeme Cooke, Vincent M. Rotello

Experimental Procedures General: All reagents were purchased from Aldrich and used without further purification unless specified below. Dimethylformamide (DMF) were purchased from VWR and used as received. All reactions were carried out under argon using oven-dried glassware. Tetrahydrofuran (THF) was distilled from sodium and benzophenone. Hexane was distilled prior to use. Dichloromethane and triethylamine were distilled from calcium hydride prior to use. 2,6-Di- $n$ propionylaminopyridone $^{1}$ and 3,4,5-Tris(n-dodecan-1-yloxy)benzylchloride ${ }^{2}$ were synthesized according to previous reports. S-1S and $\mathbf{S - 1} R$ were synthesized from $(S)$ and $(R)$ - citronellylbromide according to the adapted procedure for 3,4,5-Tris $(n$ dodecan-1-yloxy)benzylchloride. Deuterated chroloform was purchased, and deuterated $n$-hexane- $d_{14}$ was donated from Cambridge Isotope Laboratories Inc. and used as received. Elemental analysis was performed by the Microanalytical Lab at the University of Massachusetts, Amherst.

Instrumentation: ${ }^{1} \mathrm{H}$ NMR spectra were recorded using a Bruker Avance $400 \mathrm{MHz}$ spectrometer equipped with 5-mm bbo probes. Specific optical rotations were recorded on Rudolph Research Autopol III polarimeter using a 10-cm cell. Ultraviolet-Visible (UV) and Circular Dichroism (CD) spectra were recorded on Jasco J-720 spectrophotometer using a quartz cuvette with $10-\mathrm{mm}$ path length. Dynamic light scattering (DLS) experiments were performed on a Malvern Zetasizer Nano ZS using a quartz cuvette with $10-\mathrm{mm}$ path length. 
Scheme S1. Synthesis of DAP 1S-R and flavin 2,2S and 3.
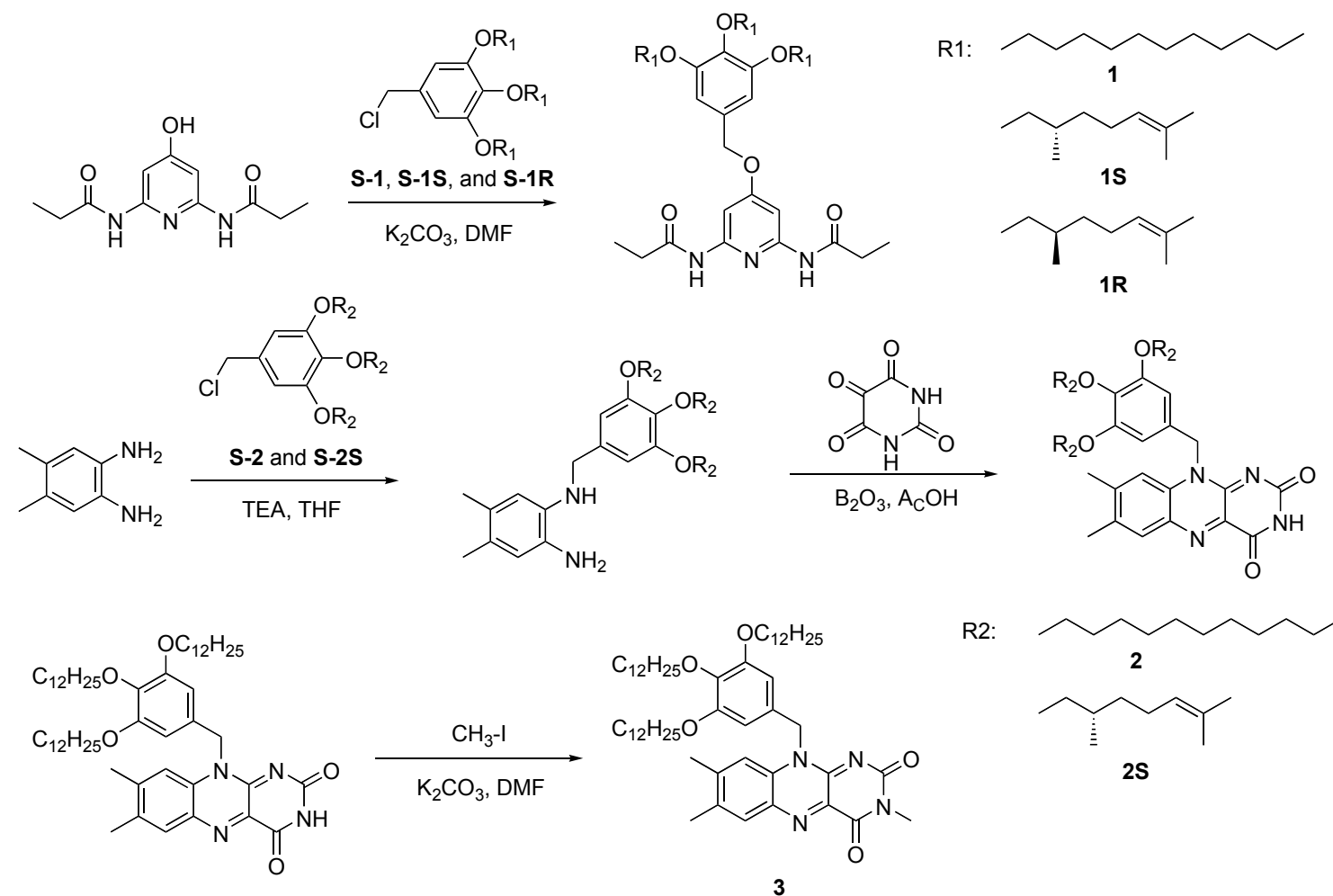

R2:

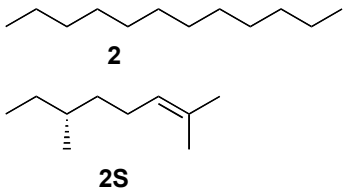

Synthesis of 1: A solution of 2,6-Di- $n$-propionylaminopyridone $(120 \mathrm{mg}, 0.5 \mathrm{mmol})$ and $\mathrm{K}_{2} \mathrm{CO}_{3}$ (200mg, 1.5mmol) in DMF (1ml) was prepared and purged with Ar for $15 \mathrm{~min}$. To this solution was added $\mathbf{S}-\mathbf{1}(340 \mathrm{mg}, 0.5 \mathrm{mmol})$ in DMF $(1 \mathrm{ml})$ dropwise at room temperature, stirred at $65^{\circ} \mathrm{C}$ overnight under Ar. To the reaction mixture was added water and extracted with ethylacetate. The combined extracts were washed with water and brine, dried over $\mathrm{MgSO}_{4}$ and evaporated under reduced pressure. The residue was subjected to flush column chromatography (silica gel, ethyacetate/hexanes, 1/1) to obtain a white solid $(257 \mathrm{mg}, 0.29 \mathrm{mmol}, 58 \%)$ : ${ }^{1} \mathrm{H}$ NMR $\left(400 \mathrm{MHz}, \mathrm{CDCl}_{3}, 25^{\circ} \mathrm{C}\right.$, TMS): $\mathrm{d}=7.66(\mathrm{~s}, 2 \mathrm{H}), 7.46(\mathrm{~s}, 2 \mathrm{H}), 6.62(\mathrm{~s}, 2 \mathrm{H}), 5.03(\mathrm{~s}, 2 \mathrm{H}), 3.98\left(\mathrm{t},{ }^{3} J(\mathrm{H}, \mathrm{H})=6.4\right.$ $\mathrm{Hz}, 4 \mathrm{H}), 3.941\left(\mathrm{t},{ }^{3} J(\mathrm{H}, \mathrm{H})=6.6 \mathrm{~Hz}, 2 \mathrm{H}\right), 2.40\left(\mathrm{q},{ }^{3} J(\mathrm{H}, \mathrm{H})=7.6 \mathrm{~Hz}, 4 \mathrm{H}\right), 1.84-1.68$ $(\mathrm{m}, 6 \mathrm{H}), 1.53-1.19(\mathrm{~m}, 60 \mathrm{H}), 0.88 \mathrm{ppm}\left(\mathrm{t},{ }^{3} J(\mathrm{H}, \mathrm{H})=6.8 \mathrm{~Hz}, 9 \mathrm{H}\right)$.

Synthesis of 1S: Adapted procedure for 1 was employed; 2,6-Di- $n$ propionylaminopyridone $(70 \mathrm{mg}, 0.3 \mathrm{mmol}), \mathrm{K}_{2} \mathrm{CO}_{3}(120 \mathrm{mg}, 0.9 \mathrm{mmol})$, and $\mathbf{S}-1 \mathrm{~S}$ (174mg, $0.3 \mathrm{mmol})$ were used to yield colorless oil $(156 \mathrm{mg}, 0.20 \mathrm{mmol}, 66 \%):{ }^{1} \mathrm{H}$ NMR $\left(400 \mathrm{MHz}, \mathrm{CDCl}_{3}, 25^{\circ} \mathrm{C}, \mathrm{TMS}\right): \mathrm{d}=7.66(\mathrm{~s}, 2 \mathrm{H}), 7.47(\mathrm{~s}, 2 \mathrm{H}), 6.63(\mathrm{~s}, 2 \mathrm{H}), 5.11\left(\mathrm{t},{ }^{3} J\right.$ $(\mathrm{H}, \mathrm{H})=7.0 \mathrm{~Hz}, 3 \mathrm{H}), 5.04(\mathrm{~s}, 2 \mathrm{H}), 4.08-3.91(\mathrm{~m}, 6 \mathrm{H}), 2.40\left(\mathrm{q},{ }^{3} J(\mathrm{H}, \mathrm{H})=7.4 \mathrm{~Hz}, 4 \mathrm{H}\right)$, $2.11-1.33(\mathrm{~m}, 39 \mathrm{H}), 1.23\left(\mathrm{t},{ }^{3} J(\mathrm{H}, \mathrm{H})=7.6 \mathrm{~Hz}, 6 \mathrm{H}\right), 0.96\left(\mathrm{~d},{ }^{3} J(\mathrm{H}, \mathrm{H})=6.8 \mathrm{~Hz}, 6 \mathrm{H}\right)$, $0.93 \mathrm{ppm}\left(\mathrm{d},{ }^{3} J(\mathrm{H}, \mathrm{H})=6.8 \mathrm{~Hz}, 3 \mathrm{H}\right) ;[\alpha]_{\mathrm{D}}{ }^{25}=-6.0^{\circ}(\mathrm{c}=1.0$ in $n$-hexanes $)$; elemental analysis calcd (\%) for $\mathrm{C} 48 \mathrm{H} 75 \mathrm{~N} 3 \mathrm{O} 6$ : $\mathrm{C}, 72.96 ; \mathrm{H}, 9.57$; N, 5.32; found: $\mathrm{C}, 72.76$; $\mathrm{H}$, $9.37 ; \mathrm{N}, 5.13$.

Synthesis of 1R: Adapted procedure for 1 was employed; 2,6-Di- $n$ propionylaminopyridone $(70 \mathrm{mg}, 0.3 \mathrm{mmol}), \mathrm{K}_{2} \mathrm{CO}_{3}(120 \mathrm{mg}, 0.9 \mathrm{mmol})$, and $\mathbf{S}-1 \mathbf{R}$ (174mg, 0.3mmol) were used to yield colourless oil (200mg, $0.25 \mathrm{mmol}, 84 \%):{ }^{1} \mathrm{H}$ NMR 
(400MHz, $\left.\mathrm{CDCl}_{3}, 25^{\circ} \mathrm{C}, \mathrm{TMS}\right): \mathrm{d}=7.66(\mathrm{~s}, 2 \mathrm{H}), 7.48(\mathrm{~s}, 2 \mathrm{H}), 6.63(\mathrm{~s}, 2 \mathrm{H}), 5.11\left(\mathrm{t},{ }^{3} J\right.$ $(\mathrm{H}, \mathrm{H})=7.2 \mathrm{~Hz}, 3 \mathrm{H}), 5.04(\mathrm{~s}, 2 \mathrm{H}), 4.09-3.90(\mathrm{~m}, 6 \mathrm{H}), 2.40\left(\mathrm{q},{ }^{3} J(\mathrm{H}, \mathrm{H})=7.6 \mathrm{~Hz}, 4 \mathrm{H}\right)$, 2.10-1.33 (m, 39H), $1.24\left(\mathrm{t},{ }^{3} J(\mathrm{H}, \mathrm{H})=7.4 \mathrm{~Hz}, 6 \mathrm{H}\right), 0.96\left(\mathrm{~d},{ }^{3} J(\mathrm{H}, \mathrm{H})=6.8 \mathrm{~Hz}, 6 \mathrm{H}\right)$, $0.93 \mathrm{ppm}\left(\mathrm{d},{ }^{3} J(\mathrm{H}, \mathrm{H})=6.8 \mathrm{~Hz}, 3 \mathrm{H}\right) ;[\alpha]_{\mathrm{D}}{ }^{25}=+7.0^{\circ}$ (c=1.0 in $n$-hexanes); elemental analysis calcd (\%) for $\mathrm{C} 48 \mathrm{H} 75 \mathrm{~N} 3 \mathrm{O} 6$ : $\mathrm{C}, 72.96$; $\mathrm{H}, 9.57$; N, 5.32; found: $\mathrm{C}, 72.45$; $\mathrm{H}$, 9.26; N, 5.10.

Synthesis of S-2: To a solution of 4,5-dimethyl-1,2-phenylenediamine (2.6g, 20mmol) and triethylamine $(6 \mathrm{ml})$ in THF $(20 \mathrm{ml})$ was added a solution of 3,4,5-Tris $(n$-dodecan-1yloxy)benzylchloride $(7.0 \mathrm{~g}, 10 \mathrm{mmol})$ in THF $(20 \mathrm{ml})$ dropwise at room temperature. After stirring for 4 days at room temperature, the solvent was evaporated and the residue was subjected to flash chromatography on silica gel (ethylacetate/hexanes, 1/4) to yield a yellow solid $(3.8 \mathrm{~g}, 4.9 \mathrm{mmol}, 49 \%)$.

Synthesis of S-2S: To a solution of 4,5-dimethyl-1,2-phenylenediamine (272mg, $2 \mathrm{mmol})$ and triethylamine $(0.6 \mathrm{ml})$ in THF $(2 \mathrm{ml})$ was added a solution of S-1S $(589 \mathrm{mg}$, $1 \mathrm{mmol})$ in THF $(1 \mathrm{ml})$ dropwise at room temperature. After stirring for 4 days at room temperature, the solvent was evaporated and the residue was subjected to flash chromatography on silica gel (ethylacetate/hexanes, 1/4) to yield a yellow solid (340mg, $0.49 \mathrm{mmol}, 49 \%$ ).

Synthesis of 2: A solution of $\mathbf{S - 2}(3.8 \mathrm{~g}, 4.9 \mathrm{mmol})$, alloxane $(0.7 \mathrm{~g}, 4.9 \mathrm{mmol})$ and $\mathrm{B}_{2} \mathrm{O}_{3}$ $(0.68 \mathrm{~g}, 4.9 \mathrm{mmol})$ in a glacial acetic acid $(100 \mathrm{ml})$ was prepared and stirred for $30 \mathrm{~min}$ at $60^{\circ} \mathrm{C}$. The reaction mixture was diluted with water to quench the reaction. The precipitates were filtered, and filtrate was extracted with $\mathrm{CH}_{2} \mathrm{Cl}_{2}$. The extracts were washed with water and dried over $\mathrm{MgSO}_{4}$. The organic fractions and precipitates were combined and evaporated under reduced pressure. The crude product was purified with flash column chromatography (silica gel, dichlomethane/methanol, 95/5) to yield a yellow solid (1.4g, 1.6mmol, 32\%): m.p. $205-206^{\circ} \mathrm{C} ;{ }^{1} \mathrm{H} \mathrm{NMR}\left(400 \mathrm{MHz}, \mathrm{CDCl}_{3}, 25^{\circ} \mathrm{C}\right.$, TMS): $\mathrm{d}=8.44(\mathrm{~s}, 1 \mathrm{H}), 8.06(\mathrm{~s}, 1 \mathrm{H}), 7.42(\mathrm{~s}, 1 \mathrm{H}), 6.40(\mathrm{~s}, 2 \mathrm{H}), 5.87(\mathrm{~s}, 2 \mathrm{H}), 3.90\left(\mathrm{t},{ }^{3} J\right.$ $(\mathrm{H}, \mathrm{H})=6.8 \mathrm{~Hz}, 2 \mathrm{H}), 3.86\left(\mathrm{t},{ }^{3} J(\mathrm{H}, \mathrm{H})=6.6 \mathrm{~Hz}, 4 \mathrm{H}\right), 2.45(\mathrm{~s}, 3 \mathrm{H}), 2.43(\mathrm{~s}, 3 \mathrm{H}), 1.79-$ $1.65(\mathrm{~m}, 6 \mathrm{H}), 1.50-1.17(\mathrm{~m}, 54 \mathrm{H}), 0.88\left(\mathrm{t},{ }^{3} \mathrm{~J}(\mathrm{H}, \mathrm{H})=6.8 \mathrm{~Hz}, 9 \mathrm{H}\right)$; elemental analysis calcd (\%) for C55H88N4O5: C, 74.62; H, 10.02; N, 6.33; found: C, 74.47; H 10.01; N, 6.23 .

Synthesis of 2S: A solution of S-2S (340mg, 0.49mmol), alloxane (70mg, 0.49mmol) and $\mathrm{B}_{2} \mathrm{O}_{3}(68 \mathrm{mg}, 0.49 \mathrm{mmol})$ in a glacial acetic acid $(10 \mathrm{ml})$ was prepared and stirred for $30 \mathrm{~min}$ at $60^{\circ} \mathrm{C}$. The reaction mixture was diluted with water to quench the reaction. The precipitates were filtered, and filtrate was extracted with $\mathrm{CH}_{2} \mathrm{Cl}_{2}$. The extracts were washed with water and dried over $\mathrm{MgSO}_{4}$. The organic fractions and precipitates were combined and evaporated under reduced pressure. The crude product was purified with flash column chromatography (silica gel, dichlomethane/methanol, 95/5) to yield a yellow solid (170mg, 0.21 mmol, 44\%): ${ }^{1} \mathrm{H}$ NMR (400MHz, $\left.\mathrm{CDCl}_{3}, 25^{\circ} \mathrm{C}, \mathrm{TMS}\right)$ : $\mathrm{d}=8.44(\mathrm{~s}, 1 \mathrm{H}), 8.06(\mathrm{~s}, 1 \mathrm{H}), 7.43(\mathrm{~s}, 1 \mathrm{H}), 6.41(\mathrm{~s}, 2 \mathrm{H}), 5.88(\mathrm{~s}, 2 \mathrm{H}), 5.07(\mathrm{~m}, 3 \mathrm{H}), 3.93-$ $3.88(\mathrm{~m}, 6 \mathrm{H}), 2.45(\mathrm{~s}, 3 \mathrm{H}), 2.42(\mathrm{~s}, 3 \mathrm{H}), 1.97-1.13(\mathrm{~m}, 39 \mathrm{H}), 0.92-0.89 \mathrm{ppm}(\mathrm{m}, 9 \mathrm{H})$.

Synthesis of 3: To a dry DMF (200ml) suspension of $2(100 \mathrm{mg}, 0.11 \mathrm{mmol})$ and $\mathrm{K}_{2} \mathrm{CO}_{3}$ (93mg, $0.66 \mathrm{mmol})$ was added iodomethane $(710 \mathrm{mg}, 5 \mathrm{mmol})$ dropwise at room temperature and the mixture was heated at $60^{\circ} \mathrm{C}$ overnight. After cooled to room temperature, the reaction was quenched by the addition of water and the aqueous mixture was extracted with ethylacetate. Combined extracts were washed with water and brine, dried over $\mathrm{MgSO}_{4}$ and evaporated under reduced pressure. The crude product 
was purified with flash column chromatography (silica gel, dichloromethane/methanol, 98/2) to yield a yellow solid (70mg, $0.078 \mathrm{mmol}, 70 \%$ ): m.p. $150-151{ }^{\circ} \mathrm{C} ;{ }^{1} \mathrm{H}$ NMR $\left(400 \mathrm{MHz}, \mathrm{CDCl}_{3}, 25^{\circ} \mathrm{C}, \mathrm{TMS}\right): \mathrm{d}=8.07(\mathrm{~s}, 1 \mathrm{H}), 7.38(\mathrm{~s}, 1 \mathrm{H}), 6.37(\mathrm{~s}, 2 \mathrm{H}), 5.86(\mathrm{~s}, 2 \mathrm{H})$, $3.89\left(\mathrm{t},{ }^{3} \mathrm{~J}(\mathrm{H}, \mathrm{H})=6.6 \mathrm{~Hz}, 2 \mathrm{H}\right), 3.84\left(\mathrm{t},{ }^{3} \mathrm{~J}(\mathrm{H}, \mathrm{H})=6.4 \mathrm{~Hz}, 4 \mathrm{H}\right), 3.55(\mathrm{~s}, 3 \mathrm{H}), 2.43(\mathrm{~s}$, $3 \mathrm{H}), 2.41(\mathrm{~s}, 3 \mathrm{H}), 1.74-1.65(\mathrm{~m}, 6 \mathrm{H}), 1.50-1.20(\mathrm{~m}, 54 \mathrm{H}), 0.88\left(\mathrm{t},{ }^{3} J(\mathrm{H}, \mathrm{H})=6.6 \mathrm{~Hz}\right.$, 9H); elemental analysis calcd (\%) for $\mathrm{C} 56 \mathrm{H} 90 \mathrm{~N} 4 \mathrm{O} 5$ : $\mathrm{C}, 74.47 ; \mathrm{H}, 10.09$; $\mathrm{N}, 6.23$; found: $\mathrm{C}, 74.61 ; \mathrm{H}, 10.05 ; \mathrm{N}, 6.16$.

(1) Ilhan, F.; Galow, T. H.; Gray, M.; Clavier, G.; Rotello, V. M. J. Am. Chem. Soc. 2000, 122, 5895-5896.

(2) Balagurusamy, V. S. K.; Ungar, G.; Percec, V.; Johansson, G. J. Am. Chem. Soc. 1997, 119, 1539-1555. 


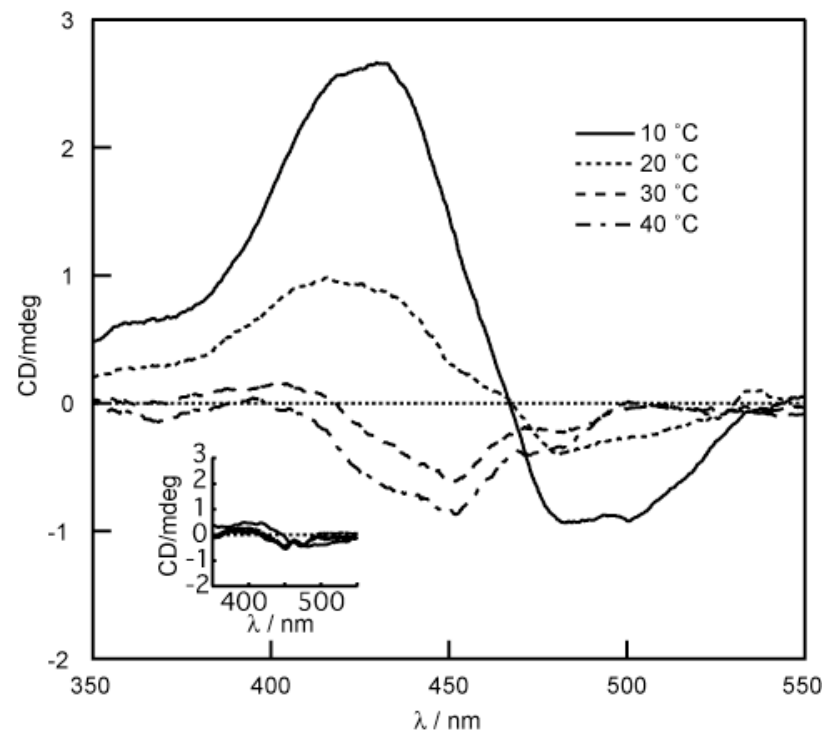

Figure S1. Variable temperature CD spectra of (S)-Dyad (DAP 1S and flavin 2) in cyclohexane (total concentration: $400 \mathrm{mM}, 10-40^{\circ} \mathrm{C}, 10 \mathrm{~mm}$ path).; inset showing control experiments using variable temperature CD spectra of (S)-DAP and $N$-methyl flavin (1S and 3 ) in cyclohexane (total concentration: $400 \mathrm{mM}, 10-40^{\circ} \mathrm{C}, 10 \mathrm{~mm}$ path).

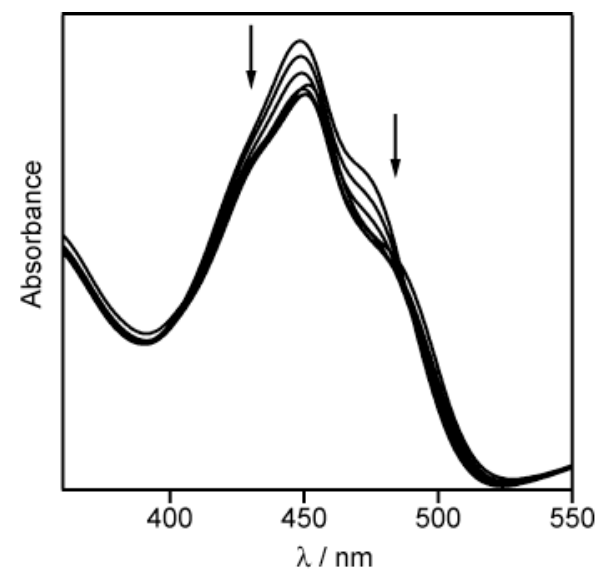

Figure S2. UV spectra of a 1:1 mixture of $\mathbf{1 S}$ and $\mathbf{2}((S)$-Dyad) were recorded in the temperature range of -10 and $50^{\circ} \mathrm{C}$ in $n$-hexane. Arrows indicate changes upon decreasing of temperature. Hypochromic effect was observed in the flavin visible region, indicative of $\pi-\pi$ stacking of flavins. 

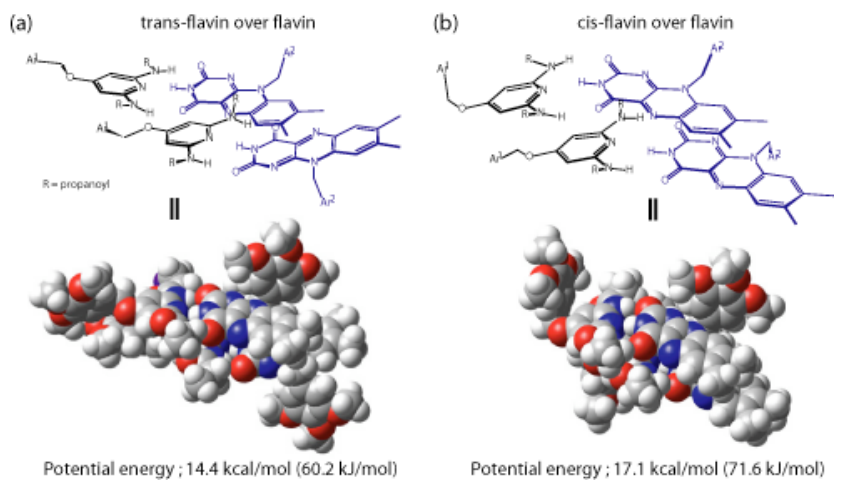

Figure S3. Energy-optimized structures of two possible tetramolecular arrangements; side chains are omitted for clarification. 